\title{
Comment on Volodichev et al. Archean Zircons with Omphacite Inclusions from Eclogites of the Belomorian Province, Fennoscandian Shield: The First Finding. Minerals 2021, 11, 1029
}

\author{
Sergey G. Skublov ${ }^{1,2, *(0)}$, Aleksey V. Berezin ${ }^{1}$ and Laysan I. Salimgaraeva ${ }^{1,2}$ (1) \\ 1 Institute of Precambrian Geology and Geochronology, Russian Academy of Sciences, \\ 199034 St. Petersburg, Russia; berezin-geo@yandex.ru (A.V.B.); fluoritecaf2@mail.ru (L.I.S.) \\ 2 Faculty of Geological Prospecting, Saint-Petersburg Mining University, 199106 St. Petersburg, Russia \\ * Correspondence: skublov@yandex.ru
}

check for

updates

Citation: Skublov, S.G.; Berezin, A.V.;

Salimgaraeva, L.I. Comment on

Volodichev et al. Archean Zircons with Omphacite Inclusions from Eclogites of the Belomorian Province, Fennoscandian Shield: The First Finding. Minerals 2021, 11, 1029. Minerals 2022, 12, 141. https:// doi.org/10.3390/min12020141

Academic Editor: José Francisco Molina

Received: 25 November 2021

Accepted: 19 January 2022

Published: 25 January 2022

Publisher's Note: MDPI stays neutral with regard to jurisdictional claims in published maps and institutional affiliations.

Copyright: (c) 2022 by the authors. Licensee MDPI, Basel, Switzerland. This article is an open access article distributed under the terms and conditions of the Creative Commons Attribution (CC BY) license (https:// creativecommons.org/licenses/by/ $4.0 /)$.

\begin{abstract}
Volodichev et al. (Volodichev et al., 2021) reported on the first finding of omphacite (23\%-25\% Jd) inclusions in 2.68 Ga metamorphic zircons from Gridino eclogites and presented it as evidence for Archean eclogite-facies metamorphism in the Belomorian Mobile Belt. We believe that the Archean age of the garnets referred to by the above authors was estimated incorrectly. Our interpretation is that omphacite origin is related to Archean high-pressure granulite-facies metamorphism.
\end{abstract}

Keywords: eclogite; zircon; omphacite; geochronology; geochemistry; mineral inclusion; Gridino eclogites; Belomorian Mobile Belt

Eclogites in the Belomorian mobile belt (BMB) provide the key for the geodynamic reconstruction of not only $\mathrm{BMB}$ but also the entire Fennoscandian Shield. One of the major problems in the study of BMB eclogites is determining the timing of their formation. Some researchers interpret BMB eclogites as Archean, thus applying modern geodynamic plate tectonic mechanisms to this Archean crust segment. Available geochronological data on BMB eclogites are interpreted in various ways. The dominant point of view of the Paleoproterozoic age of BMB eclogites is based on the results of a set of independent isotopic-geochemical dating methods, such as the local U-Pb method for heterogeneous zircons with magmatic cores and eclogite rims, as well as the Lu-Hf and Sm-Nd methods for rock-forming minerals of eclogite paragenesis. All three methods independently show that eclogite-facies metamorphism is of Svecofennian age and yield the same value, $\sim 1.9$ Ga [1-7].

Therefore, the authors [8] believe that the omphacite inclusion in zircon of Archean age from an eclogite boudin found on Stolbikha Island in the Gridino area is an indisputable argument in favor of the Archean age of BMB eclogites. However, the attentive reader of the above contribution can notice that the evidence obtained by the authors, as well as the results of earlier studies, are misrepresented.

1. The above authors strongly argue that the Archean age for garnets from BMB eclogites was estimated earlier using the U-Pb method [9]. However, it is clear from the source referred to (an abstract) that no concordant age values for the analyzed garnets (21 samples) have been obtained (Figure 1). A discordia line with an age of $1866 \pm 44 \mathrm{Ma}$ was plotted for some of the analytical points, and another discordia line with an age of $2747 \pm 52 \mathrm{Ma}$ was constructed for other points. An MSWD value for both discordia lines was not given. The plot only shows figurative points rather than ellipses of mistakes, which can be analyzed to check the validity of the evidence presented. 


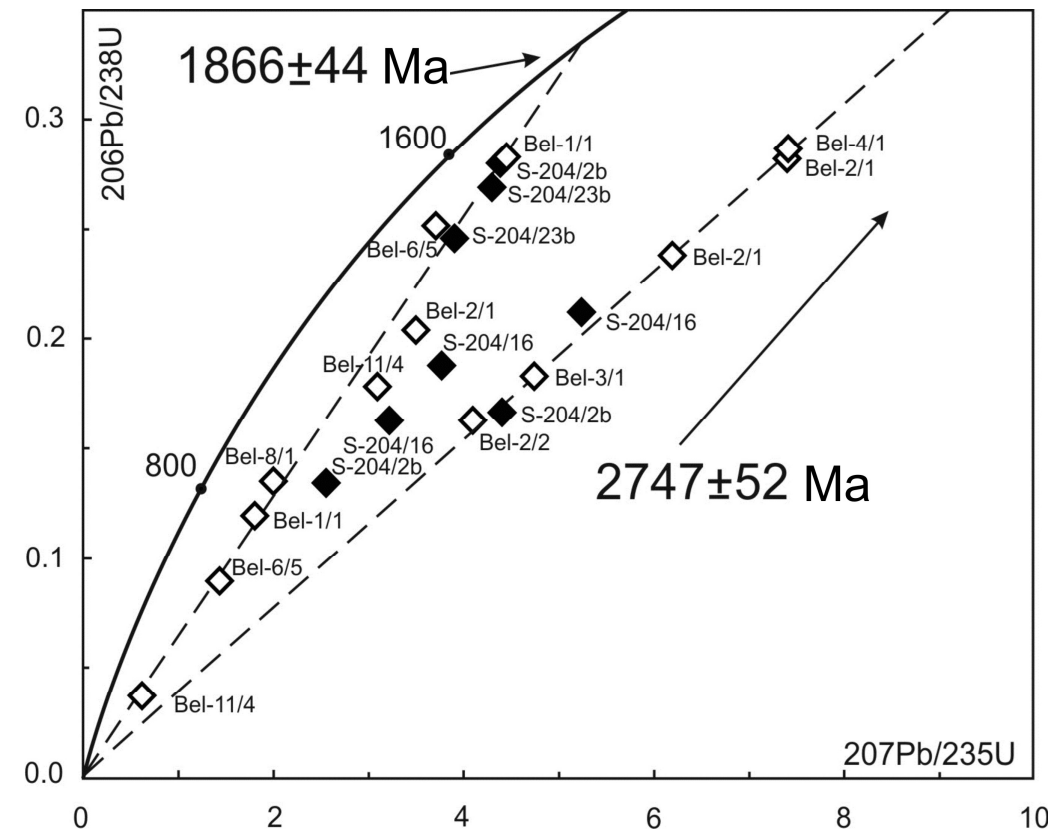

Figure 1. U-Pb diagram for garnets from eclogites of BMB (modified after [9]). Filled diamonds are garnets from Salma eclogites, white diamonds are garnets from Gridino eclogites.

With respect to the $\mathrm{U}-\mathrm{Pb}$ method used for the analysis of the garnets, it should be noted that the garnets were treated with warm $2 \mathrm{~N} \mathrm{HCl}$ for $20 \mathrm{~min}$ prior to a dissolving procedure, which could result in a considerable loss of lead. The experiments (unpublished data IPGG RAS) have shown that the treatment of garnets with $0.05 \mathrm{~N} \mathrm{HCl}$ and $0.25 \mathrm{~N}$ $\mathrm{HCl}$ solutions for one hour at $80{ }^{\circ} \mathrm{C}$ results in the loss of $30 \%$ to $40 \%$ of lead. Thus, the discordance of the analyzed samples is assumed to have been caused by the disturbance of the $\mathrm{U}-\mathrm{Pb}$ system of the garnets during the preliminary treatment of the mineral. This assumption is supported by the «zero» intersection of the plotted discordia lines (Figure 1). Furthermore, the garnets were dissolved in a mixture of $\mathrm{HF}$ and $\mathrm{HNO}_{3}$ at $\sim 200{ }^{\circ} \mathrm{C}$ for $48 \mathrm{~h}$. It is known that such sample preparation conditions are commonly used for the dissolving of zircons. Therefore, it is assumed that micron-sized zircon inclusions were dissolved or at least affected. As garnets from BMB eclogites contain no radiogenic lead (Skublov, unpublished data), they cannot be used as a $\mathrm{U}-\mathrm{Pb}$ geochronometer. The age of $2747 \pm 52 \mathrm{Ma}$ is, in fact, the age of zircon inclusions analyzed in garnet. This age practically coincides with that of zircons from the same eclogite boudin found on Stolbikha Island in the Gridino area $(2743 \pm 10 \mathrm{Ma})$, whose age was interpreted as the timing of granulite-facies metamorphism, which preceded $\sim 1.9$ Ga eclogite-facies metamorphism [6].

The results of the Sm-Nd dating of the garnets seem to be more valid, because the possible presence of zircon in the garnet does not affect the behavior of the Sm-Nd system [10]. We dated garnets from Gridino eclogites using the Sm-Nd method with a preliminary treatment of the garnets with high-purity $\mathrm{H}_{2} \mathrm{SO}_{4}$ based on the technique described in [11]. As a result, we obtained an isochrone with an age of $1911 \pm 11 \mathrm{Ma}$ (MSWD = 0.61), which coincided with the age of eclogite zircons from the same sample [2]. The dating of garnets from Gridino eclogites using the Lu-Hf method also yielded ages of $1937 \pm 8 \mathrm{Ma}$ and $1892 \pm 10 \mathrm{Ma}$ [3]. Similar ages of 1.96-1.92 Ga were obtained by garnet Lu-Hf geochronology for Gridino eclogites [5].

Thus, we believe that the Archean U-Pb age of Gridino eclogites is not strictly proven. It contradicts the results of garnet dating by other methods ( $\mathrm{Sm}-\mathrm{Nd}, \mathrm{Lu}-\mathrm{Hf}$ ) and seems to be consistent with the age of micron-sized zircon inclusions in garnet; therefore, it cannot indicate the time of eclogite formation.

2. The authors' conclusions are based on the scarcity of their data. Only two (!) omphacite inclusions were found in the cores of Archean zircons. The biggest inclusion, 
$\sim 5 \times 20 \mu \mathrm{m}$ in size, is in the zircon (grain 7), which the authors did not date. It is, therefore, incorrect to draw conclusions about the age of the zircon and, hence, the age of the omphacite inclusion in it solely from the «similarity» of the CL-image of the zircon to other dated zircon. The other omphacite inclusion, only $3.8 \times 1.9 \mu \mathrm{m}$ in size (grain 13), is too small to be reliably analyzed by SEM-EDS method.

Even if the omphacite in the zircon core was analyzed correctly, we do not think that it was derived under eclogite-facies conditions. The $25 \% \mathrm{Jd}$ content of the omphacite is similar to the lower limit for omphacite [12]. Omphacite-hosting zircon has a ${ }^{207} \mathrm{~Pb} /{ }^{206} \mathrm{~Pb}$ age of $2694.1 \pm 8.1 \mathrm{Ma}$ (Table 1, spot 13.1; [8]). The age of 2.7 Ga, estimated from the zircon cores, was interpreted by us as the timing of granulite-facies regional metamorphism in BMB [6]. The formation of omphacite under high-pressure granulite-facies metamorphic conditions has been repeatedly proven, for example, for Bohemian Massif (up to 27\% Jd, [13]) and Western Sudetes (up to 32.6\% Jd, [14]) granulites. The parameters of metamorphism for Gridino eclogites (14 kbar and $750{ }^{\circ} \mathrm{C}$ [15]), calculated from omphacite inclusions in garnet with $23 \% \mathrm{Jd}$, are also consistent with high-pressure granulites rather than eclogites [16].

The paragenesis of the rock-forming minerals corresponding to $\sim 2.7$ Ga granulitefacies metamorphism are obscured in this part of BMB by active $~ 1.9$ Ga eclogite-facies metamorphism. Therefore, a correct interpretation of geochronological data for zircons is critical. The typical geochemical characteristics of typical eclogite-facies zircons are well-known $[17,18]$. An anomalously low Th content (no more than 3 ppm on average) and Th/U value (0.03 on average), much lower REE (less than $22 \mathrm{ppm}$ ) and especially LREE (less than 2 ppm) contents, and a lowered Y (34 ppm on average) are generally observed. REE distribution spectra for eclogite zircons display a well-defined flat HREE pattern, no or poorly defined negative Eu-anomaly, and a strongly reduced positive Ce-anomaly [18].

The zircon core with a micron-sized omphacite inclusion contains 275 ppm REE (131 ppm LREE and 144 ppm HREE), 126 ppm Y, 48 ppm Th and a Th/U ratio $=0.21$ (Tables 1 and 2, Spot 13.1; [8]). A comparison of these parameters with median values for typical eclogite zircons [18] shows that they are inconsistent. The inconsistency is especially obvious from the Th concentration and the Th/U ratio. A zircon core (grain 13) with such a composition cannot be interpreted as eclogitic.

Furthermore, the authors do not rule out the magmatic origin of the zircon cores but define some cores as eclogitic due to the presence of omphacite inclusions.

3. There are other considerable inconsistencies in the paper discussed [8]. Micronsized garnet inclusions were found only in Svecofennian $\sim 1.9$ Ga zircon rims (Figure 4, grains 4 and 11; [8]). Why have no garnets, occurring together with omphacite, been found in zircon cores of Archean age? When describing the composition of the garnets, andradite end-member is described. More detailed comments are needed because $\mathrm{Fe}^{3+}$ cannot be analyzed by the SEM-EDS method.

The authors [8] reported that garnet in massive eclogites contains both omphacite and amphibole inclusions. Figure 3 shows that omphacite with $28 \%-30 \%$ Jd is in the rock matrix (Figure 3a) and that compositionally similar omphacite occurs as inclusions in the garnet together with chlorine-bearing pargasite (Figure 3b). Figure 4 shows that the zircon core (grain 19) contains a high-Mg hornblende inclusion. Similar cores (grains 7 and 13) were shown to contain omphacite $(23 \%-25 \% \mathrm{Jd})$. Does this mean that amphibole and omphacite are in equilibrium and were trapped simultaneously? Garnet-omphacite-amphibole paragenesis is unlikely for classical eclogites. How, then, does this agree with the fact that pargasite in zircon (grain 13) is in $1.9 \mathrm{Ga}$ zircon rim. According to the phase correspondence theory [19], as pressure increases, the reaction $\mathrm{Cpx}^{\mathrm{Fe}}+\mathrm{Amp}^{\mathrm{Mg}}=\mathrm{Cpx} \mathrm{Mg}^{\mathrm{Mg}} \mathrm{Amp} \mathrm{Fe}^{\mathrm{Fe}}$ shifted to the right, i.e., high-Fe rather than high-Mg amphibole would be in equilibrium with high-Mg clinopyroxene, as follows from the authors' data.

The authors argue that the peak stage parameters of eclogite-facies metamorphism are 18.5 kbar и 695-755 ${ }^{\circ} \mathrm{C}$. However, in accordance with the reaction $\mathrm{Ab}=\mathrm{Jd}+\mathrm{Qz}$, at such a pressure the rock is expected to contain practically pure jadeite [20], but only $23 \%-25 \% \mathrm{Jd}$ omphacite is reported. 
Thus, the authors [8] have drawn a far-reaching conclusion about the existence of Archean eclogites in BMB on the basis of only two finds of micron-sized omphacite inclusions in zircon. The authors' conclusions are largely supported by earlier $\mathrm{U}-\mathrm{Pb}$ dating of garnets, which, when analyzed in detail, is completely unsubstantiated. The composition of Archean zircons has nothing in common with that of typical zircons from the world's eclogite complexes [18]. The authors ignore the option that an omphacite inclusion and the $\sim 2.7 \mathrm{Ga}$ zircon that hosts it may indicate high-pressure granulite-facies metamorphism, in which omphacite with a moderate Jd content may be present.

It should be added that the interpretation of the origin of a rock on the basis of micron-sized mineral inclusions alone may lead to incorrect results. Some time ago, the journal Nature reported the finding of Hadean diamonds in zircon from Jack Hills, Western Australia [21]. This was assumed to be a major discovery in geology. However, it was proven later that the diamonds were the result of contamination during sample preparation [22]. Of course, the omphacite found in zircon is a fact, but the interpretation of this fact, as well as the results of earlier studies, do not support the Archean age of the eclogites.

The above evidence has led us to conclude that the paper [8] is interesting but debatable. The Archean age of BMB eclogites can only be estimated by dating rock-forming and accessory minerals by independent isotopic geochemical methods, as has been done to support the Paleoproterozoic age of BMB eclogites (e.g., $[2,3,6,7])$.

Author Contributions: Conceptualization, S.G.S. and A.V.B.; investigation, S.G.S., A.V.B. and L.I.S.; writing-original draft preparation, S.G.S., A.V.B. and L.I.S.; writing-review and editing, S.G.S., A.V.B. and L.I.S.; supervision, S.G.S.; project administration, S.G.S. All authors have read and agreed to the published version of the manuscript.

Funding: This study was conducted under state contracts No. FMUW-2022-0005 (Institute of Precambrian Geology and Geochronology of the Russian Academy of Sciences).

Conflicts of Interest: The authors declare no conflict of interest.

\section{References}

1. Skublov, S.G.; Astaf'ev, B.Y.; Marin, Y.B.; Berezin, A.V.; Mel'nik, A.E.; Presnyakov, S.L. New data on the age of eclogites from the Belomorian Mobile Belt at Gridino settlement area. Dokl. Earth Sci. 2011, 439, 1163-1170. [CrossRef]

2. Berezin, A.V.; Travin, V.V.; Marin, Y.B.; Skublov, S.G.; Bogomolov, E.S. New U-Pb and Sm-Nd ages and P-T estimates for eclogitization in the Fe-Rich gabbro dyke in Gridino area (Belomorian Mobile Belt). Dokl. Earth Sci. 2012, 444, 760-765. [CrossRef]

3. Herwartz, D.; Skublov, S.G.; Berezin, A.V.; Mel'nik, A.E. First Lu-Hf Garnet Ages of Eclogites from the Belomorian Mobile Belt (Baltic Shield, Russia). Dokl. Earth Sci. 2012, 443, 377-380. [CrossRef]

4. Yu, H.L.; Zhang, L.F.; Wei, C.J.; Li, X.L.; Guo, J.H. Age and P-T Conditions of the Gridino eclogite in the Belomorian Province, Russia. J. Metamorph. Geol. 2017, 35, 855-869. [CrossRef]

5. Yu, H.; Zhang, L.; Lanari, P.; Rubatto, D.; Li, X. Garnet Lu-Hf geochronology and P-T path of the Gridino-type eclogite in the Belomorian Province, Russia. Lithos 2019, 326, 313-326. [CrossRef]

6. Skublov, S.G.; Berezin, A.V.; Li, X.-H.; Li, Q.-L.; Salimgaraeva, L.I.; Travin, V.V.; Rezvukhin, D.I. Zircons from a Pegmatite Cutting Eclogite (Gridino, Belomorian Mobile Belt): $\mathrm{U}-\mathrm{Pb}-\mathrm{O}$ and Trace Element Constraints on Eclogite Metamorphism and Fluid Activity. Geosciences 2020, 10, 197. [CrossRef]

7. Melnik, A.E.; Skublov, S.G.; Rubatto, D.; Müller, D.; Li, X.-H.; Li, Q.-L.; Berezin, A.V.; Herwartz, D.; Machevariani, M.M. Garnet and zircon geochronology of the Paleoproterozoic Kuru-Vaara eclogites, northern Belomorian Province, Fennoscandian Shield. Precambrian Res. 2021, 353, 106014. [CrossRef]

8. Volodichev, O.I.; Maksimov, O.A.; Kuzenko, T.I.; Slabunov, A.I. Archean Zircons with Omphacite Inclusions from Eclogites of the Belomorian Province, Fennoscandian Shield: The First Finding. Minerals 2021, 11, 1029. [CrossRef]

9. Kaulina, T.V.; Mitrofanov, F.P.; Apanasevich, E.A.; Zhavkov, V.A.; D'yakov, S.N.; Sherstennikova, O.G. U-Pb dating of garnet. In New Data on Geology and Mineral Deposits of the Kola Peninsula; Mitrofanov, F.P., Ed.; Kola Science Centre of the RAS: Apatity, Russia, 2005; pp. 60-64. (In Russian)

10. DeWolf, C.P.; Zeissler, C.J.; Halliday, A.N.; Mezger, K.; Essene, E.J. The role of inclusions in U-Pb and Sm-Nd garnet geochronology: Stepwise dissolution experiments and trace uranium mapping by fission track analysis. Geochim. Cosmochim. Acta 1996, 60, 121-134. [CrossRef]

11. Anczkiewicz, R.; Thirlwall, M.F. Improving precision of Sm-Nd garnet dating by $\mathrm{H}_{2} \mathrm{SO}_{4}$ leaching: A simple solution to the phosphate inclusion problem. Geol. Soc. Lond. Spec. Publ. 2003, 220, 83-91. [CrossRef]

12. Morimoto, N. Nomenclature of pyroxenes. Mineral. Petrol. 1988, 39, 55-76. [CrossRef] 
13. Štípská, P.; Schulmann, K.; Kröner, A. Vertical extrusion and middle crustal spreading of omphacite granulite: A model of syn-convergent exhumation (Bohemian Massif, Czech Republic). J. Metamorph. Geol. 2004, 22, 179-198. [CrossRef]

14. Kryza, R.; Pin, C.; Vielzeuf, D. High-pressure granulites from the Sudetes (south-west Poland): Evidence of crustal subduction and collisional thickening in the Variscan Belt. J. Metamorph. Geol. 1996, 14, 531-546. [CrossRef]

15. Maksimov, O.A.; Slabunov, A.I.; Balagansky, V.V.; Volodichev, O.I. Archean eclogites from the Belomorian Province (Examples from the Gridino Area). In Proceedings of the Abstract Volume of the 13th International Eclogite Conference, Karelia, Russia, 24-27 June 2019; KRC RAS: Petrozavodsk, Russia, 2019; p. 54.

16. Oh, C.W.; Liou, J.G. A petrogenetic grid for eclogite and related facies under high-pressure metamorphism. Island Arc 1998, 7, 36-51. [CrossRef]

17. Rubatto, D. Zircon trace element geochemistry: Partitioning with garnet and the link between U-Pb ages and metamorphism. Chem. Geol. 2002, 184, 123-138. [CrossRef]

18. Skublov, S.G.; Berezin, A.V.; Berezhnaya, N.G. General Relations in the Trace Element Composition of Zircons from Eclogites with Implications for the Age of Eclogites in the Belomorian Mobile Belt. Petrology 2012, 20, 427-449. [CrossRef]

19. Perchuk, L.L. The effect of temperature and pressure on the equilibrium of natural iron-magnesium minerals. Int. Geol. Rev. 1969, 11, 875-901. [CrossRef]

20. Holland, T.J. The reaction albite $=$ jadeite + quartz determined experimentally in the range $600-1200{ }^{\circ} \mathrm{C}$. Am. Mineral. 1980,65 , 129-134.

21. Menneken, M.; Nemchin, A.A.; Geisler, T.; Pidgeon, R.T.; Wilde, S.A. Hadean diamonds in zircon from Jack Hills, Western Australia. Nature 2007, 448, 917-920. [CrossRef] [PubMed]

22. Dobrzhinetskaya, L.; Wirth, R.; Green, H. Diamonds in Earth's oldest zircons from Jack Hills conglomerate, Australia, are contamination. Earth Planet. Sci. Lett. 2014, 387, 212-218. [CrossRef] 